Article

\title{
Simultaneous Measurements of Chemical Compositions of Fine Particles during Winter Haze Period in Urban Sites in China and Korea
}

\author{
Minhan Park ${ }^{1,+}{ }^{\oplus}$, Yujue Wang ${ }^{2,+}$, Jihyo Chong ${ }^{1, \ddagger}$, Haebum Lee ${ }^{1}$, Jiho Jang ${ }^{1}$, Hangyul Song ${ }^{1}$, \\ Nohhyeon Kwak ${ }^{1}$, Lucille Joanna S. Borlaza ${ }^{1,} \mathbb{S}^{\mathbb{D}}$, Hyunok Maeng ${ }^{1}$, \\ Enrique Mikhael R. Cosep 1,II, Ma. Cristine Faye J. Denna ${ }^{1}$, Shiyi Chen ${ }^{2}$, Ilhwa Seo ${ }^{1}$, \\ Min-Suk Bae ${ }^{3}$, Kyoung-Soon Jang ${ }^{4}\left(\mathbb{D}\right.$, Mira Choi ${ }^{4}$, Young Hwan Kim ${ }^{4}$, Moonhee Park ${ }^{4}$, \\ Jong-Sik Ryu ${ }^{5, \mathbb{I}}$, Sanghee Park ${ }^{5}{ }^{\mathbb{D}}$, Min $\mathrm{Hu}^{2, *}$ and Kihong Park ${ }^{1, *}$
}

1 School of Earth Sciences and Environmental Engineering, Gwangju Institute of Science and Technology, 123 Cheomdangwagiro, Buk-gu, Gwangju 61005, Korea; parkmh@gist.ac.kr (M.P.); jihyojung@gist.ac.kr (J.C.); bambam91@gist.ac.kr (H.L.); hijiho32@gist.ac.kr (J.J.); princesong@gist.ac.kr (H.S.); nohhyeon@gist.ac.kr (N.K.); lucilleborlaza@gmail.com (L.J.S.B.); mho@gist.ac.kr (H.M.); mikocosep@gmail.com (E.M.R.C.); fayedenna@gist.ac.kr (M.C.F.J.D.); ilhwa0903@gist.ac.kr (I.S.)

2 State Key Joint Laboratory of Environmental Simulation and Pollution Control, and Beijing Innovation Center for Engineering Sciences and Advanced Technology, College of Environmental Sciences and Engineering, Peking University, Beijing 100871, China; wangyujue1223@163.com (Y.W.); chenshiyi@pku.edu.cn (S.C.)

3 Department of Environmental Engineering, Mokpo National University, Muan 58554, Korea; minsbae@mokpo.ac.kr

4 Biomedical Omics Center, Korea Basic Science Institute, Cheongju 28119, Korea; ksjang@kbsi.re.kr (K.-S.J.); alfk6346@kbsi.re.kr (M.C.); yhkim@kbsi.re.kr (Y.H.K.); moonhee@kbsi.re.kr (M.P.)

5 Division of Earth and Environmental Sciences, Korea Basic Science Institute, Cheongju 28119, Korea; jongsikryu@pknu.ac.kr (J.-S.R.); psh0911@kbsi.re.kr (S.P.)

* $\quad$ Correspondence: kpark@gist.ac.kr (K.P.); minhu@pku.edu.cn (M.H.); Tel.: +82-62-715-3279 (K.P.); +86-10-6275-1920 (M.H.)

$\dagger$ These authors contributed equally to this work.

$\ddagger$ Current address: Observation and Forecast Research Division, National Institute of Meteorological Sciences, Jeju-do 690-011, Korea.

$\S$ Current address: Institute of Environmental Geosciences, University of Grenoble, 38900 Grenoble, France.

|| Current address: Institute of Environmental Science and Meteorology, University of the Philippines-Diliman, Quezon city 1101, Philippine.

II Current address: Department of Earth and Environmental Sciences, Pukyong National University, Busan 48513, Korea.

Received: 12 February 2020; Accepted: 14 March 2020; Published: 16 March 2020

check for updates

\begin{abstract}
We performed simultaneous measurements of chemical compositions of fine particles in Beijing, China and Gwangju, Korea to better understand their sources during winter haze period. We identified $\mathrm{PM}_{2.5}$ events in Beijing, possibly caused by a combination of multiple primary combustion sources (biomass burning, coal burning, and vehicle emissions) and secondary aerosol formation under stagnant conditions and/or dust sources under high wind speeds. During the $\mathrm{PM}_{2.5}$ events in Gwangju, the contribution of biomass burning and secondary formation of nitrate and organics to the fine particles content significantly increased under stagnant conditions. We commonly observed the increases of nitrogen-containing organic compounds and biomass burning inorganic $\left(\mathrm{K}^{+}\right)$and organic (levoglucosan) markers, suggesting the importance of biomass burning sources during the winter haze events (except dust event cases) at both sites. Pb isotope ratios indicated that the fraction of $\mathrm{Pb}$ originated from possibly industry and coal combustion sources increased during the $\mathrm{PM}_{2.5}$ events in Gwangju, relative to nonevent days.
\end{abstract}


Keywords: $\mathrm{PM}_{2.5}$; haze; chemical compositions; organic compounds

\section{Introduction}

Atmospheric fine particles, which are defined as particulate matter of sizes less than $2.5 \mu \mathrm{m}$ $\left(\mathrm{PM}_{2.5}\right)$, are of particular concern due to their effects on climate change (radiation balance and cloud formation) and human health [1-6]. Fine particles are produced directly from various natural and anthropogenic sources and are formed from precursor vapors by gas-to-particle conversion processes. The sources, physicochemical properties, and climate change and human health impacts of fine particles vary depending on time and locations.

Elevated $\mathrm{PM}_{2.5}$ mass concentrations are typically observed during winter haze period in Northeast Asia, including China and Korea, caused by a number of local and regional sources under specific meteorological conditions [7-11]. In winter, Korea and China are located on the downwind of winter monsoons. Wang et al. [12] reported that Southeast China was affected by long-range transported pollutants from Northern China during the cold surges. A similar behavior was also observed in Korea in winter. A combination of vehicle emission, biomass burning, industry, and resuspended dust were found to be mainly responsible for the haze in Beijing, China [13,14]. Secondary formation of inorganic and organic aerosols under humidity conditions [15], and transport of pollutants from southern industrial areas also contributed to the winter haze in Beijing [13,14]. Kim et al. [16] found the importance of secondary organic carbon contribution to $\mathrm{PM}_{2.5}$ during winter haze period in Seoul, Korea. Choi et al. [17] suggested that major sources responsible for $\mathrm{PM}_{2.5}$ during winter in Incheon, Korea were motor vehicles/sea salt (37.7\%), secondary organic aerosols $(27.2 \%)$, combustion $(20.1 \%)$, biogenic/meat cooking $(8.2 \%)$, and soils (6.9\%). It was found that carbonaceous species and secondary formation of inorganic aerosols under low wind speeds and high relative humidity contributed to winter haze in Seoul, Korea [18]. In Korea, secondary formation processes became more important contributions to the $\mathrm{PM}_{2.5}$ than primary sources. Long-term measurements of the chemical composition of $\mathrm{PM}_{2.5}$ at specific sites have been useful to examine seasonal and annual variability of $\mathrm{PM}_{2.5}$ sources. Additionally, spatial variability in the chemical composition of $\mathrm{PM}_{2.5}$ in regions of varying land use in each country was investigated to determine the source variability at different locations [6,19-21].

However, various measurement methods and nonsimultaneous measurements in different locations (i.e., measurements at different times) in China and Korea and insufficient chemical data made it difficult to directly compare characteristics of fine particles and their sources during the winter haze period in China and Korea. Thus, the simultaneous measurements of $\mathrm{PM}_{2.5}$ in different locations are necessary to effectively identify the spatial differences and similarities between major $\mathrm{PM}_{2.5}$ sources. In addition, in-depth chemical composition data, including organic compounds, molecular composition of organic carbons (high-resolution mass), and isotope ratios, can be used to better identify the variability in $\mathrm{PM}_{2.5}$ characteristics and sources in different locations. High-resolution mass spectrometric techniques can provide valuable information on thousands of organic compounds in $\mathrm{PM}_{2.5}$ to identify markers of combustion sources (e.g., biomass burning) [22] and classify organic groups (e.g., $\mathrm{CH}, \mathrm{CHO}, \mathrm{CHN}, \mathrm{CHS}$, and $\mathrm{CHON}$ organic groups) [23]. Measurements of isotope ratios have also been used as effective tracers of sources for $\mathrm{PM}_{2.5}[24,25]$.

In this study, simultaneous measurements of ions, elements, elemental carbon (EC), organic carbon (OC), organic compounds, and $\mathrm{Pb}$ isotopes of ambient $\mathrm{PM}_{2.5}$ in different urban sites (Beijing, China and Gwangju, Korea) were conducted during the winter of 2018. We examined the polar and nonpolar organic compounds (previously identified as organic markers) and the molecular compositions of water-insoluble organic carbons (WISOC) (CHO, CHN, CHS, CHON, and CHONS organic groups) to compare the characteristics of organic compounds in $\mathrm{PM}_{2.5}$ between both sites. We also compared the $\mathrm{S} / \mathrm{C}, \mathrm{N} / \mathrm{C}, \mathrm{H} / \mathrm{C}$, and $\mathrm{O} / \mathrm{C}$ elemental ratios and the high mass resolution polycyclic aromatic hydrocarbons (PAHs), hopanes, and sugar of WISOC, including gaseous $\left(\mathrm{O}_{3}, \mathrm{NO}_{2}, \mathrm{CO}\right.$, and $\left.\mathrm{SO}_{2}\right)$; meteorological; 
and air mass backward trajectory data between the sites. This comparative study at two urban sites in Northeast Asia will improve our understanding of differences and similarities in various factors causing the winter $\mathrm{PM}_{2.5}$ events in both countries and their effects on human health.

\section{Experimental Methods}

The locations of the sampling sites are shown in Figure 1. The Beijing site in China is located on the Peking University Changping Campus (PKU CP) $\left(40^{\circ} 14^{\prime} 44.6^{\prime \prime} \mathrm{N}\right.$ and $\left.116^{\circ} 11^{\prime} 33.3^{\prime \prime} \mathrm{E}\right)$. The town of Changping is subject to high emissions of various local combustion sources (coal, biomass, and vehicles) during the winter season [26]. The Gwangju site in Korea is located on the campus of the Gwangju

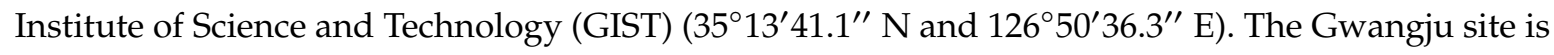
situated $\sim 8 \mathrm{~km}$ from the city center and is surrounded by agricultural, residential, and commercial areas and is also close to a main highway [20]. The sampling and measurements of $\mathrm{PM}_{2.5}$ were simultaneously conducted from Jan 3, 2018 to Feb 2, 2018 in both sites.

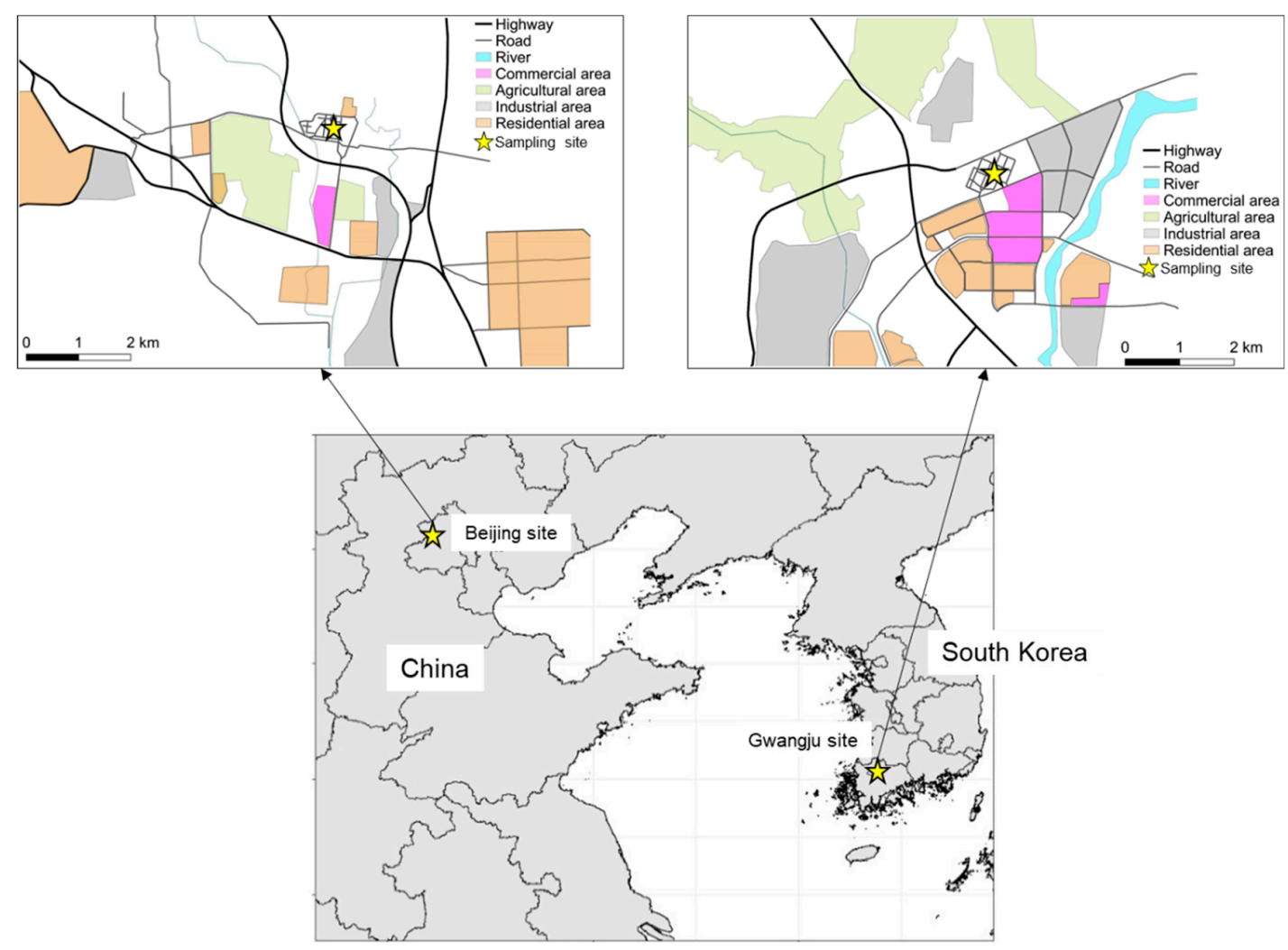

Figure 1. Map of sampling sites.

A four-channel mini-volume sampler (TH-16A, Wuhan Tianhong Instruments, Wuhan, China) and a high-volume sampler (TH-1000C, Wuhan Tianhong Instruments, China) were used to collect $\mathrm{PM}_{2.5}$ filter samples at the Beijing site. Three mini-volume samplers (URG-2000-30EH, URG, Chapel Hill, NC, USA) and two high-volume samplers (TE-6001-2.5I, Tisch Environmental, Cleves, OH, USA and HV-RW, Sibata, Soka, Japan) were used to collect $\mathrm{PM}_{2.5}$ at the Gwangju site. The sampling flow rates of the mini-volume sampler and the high-volume sampler were $16.7 \mathrm{lpm}$ and 1000-1200 lpm, respectively. Each day, the 24-h samples were collected on Teflon $(47 \mathrm{~mm})$ (Zefluor, Pall corp., New York, NY, USA), prebaked $\left(400{ }^{\circ} \mathrm{C}\right.$ for $4 \mathrm{~h}$ ) on quartz $(47 \mathrm{~mm})$ (Tissuquartz 2500QAT-UP, Pall corp., New York, NY, USA), and prebaked $\left(400^{\circ} \mathrm{C}\right.$ for $4 \mathrm{~h}$ ) on quartz ( 8 inch $\times 10$ inch) (Tissuquartz 2500QAT-UP, Pall corp., New York, NY, USA). Daily sampling times were 09:00-08:30 (next day) at the Beijing site and 10:00-09:30 (next day) at the Gwangju site. In total, 396 samples were obtained from all sites during the sampling period. Table $\mathrm{S} 1$ in supplementary material summarizes all measured parameters at both sites. 
The 24-h average $\mathrm{PM}_{2.5}$ mass concentrations were determined by gravimetric analysis using a microbalance (Cubis ${ }^{\circledR}$ MSA3.6P-000-DM, Sartorius, Goettingen, Germany). Triplicate weights of the Teflon filters before and after sampling were recorded after 24-h equilibration at constant temperature and relative humidity $\left(20.1 \pm 3.0{ }^{\circ} \mathrm{C}, 16.6 \% \pm 2.2 \%\right)$. $\mathrm{PM}_{2.5}$ events at the Beijing and Gwangju sites were defined when daily $\mathrm{PM}_{2.5}$ mass concentration exceeded $100 \mu \mathrm{g} / \mathrm{m}^{3}$ and $50 \mu \mathrm{g} / \mathrm{m}^{3}$, respectively (i.e., filter-based mass concentrations measured at the sampling sites). These values are within the top $10 \%$ during the whole sampling period at each site. Nonevent days were selected when daily $\mathrm{PM}_{2.5}$ mass concentration was less than 25 percent of the monthly average values during more than 3 consecutive days at both sites. Hourly PM2.5 and PM10 mass concentrations were measured using tapered element oscillating microbalance (TEOM, TH-2000Z1, Wuhan Tianhong instruments, Wuhan, China) and optical particles counter (OPC, 1.108, Grimm, Ainring, Germany) with a diffusion dryer to remove particle-bound water.

For ion analysis, the Teflon filter samples were extracted by 2-h ultrasonication in $30 \mathrm{~mL}$ deionized (DI) water at constant water temperature $\left(20^{\circ} \mathrm{C}\right)$. The extracted solution was subsequently filtered through a polytetrafluoroethylene (PTFE) syringe filter to remove the water insoluble fraction. Eight water-soluble ions $\left(\mathrm{SO}_{4}{ }^{2-}, \mathrm{NO}_{3}{ }^{-}, \mathrm{Cl}^{-}, \mathrm{NH}_{4}{ }^{+}, \mathrm{Na}^{+}, \mathrm{K}^{+}, \mathrm{Mg}^{2+}\right.$, and $\left.\mathrm{Ca}^{2+}\right)$ were analyzed by ion chromatography (IC) (850 Professional IC, Metrohm, Herisaus, Switzerland). Method of detection limits (MDLs) were in the range of $<0.001-0.04 \mathrm{ppm}$. Non-sea salt $\mathrm{SO}_{4}{ }^{2-}$ ion was estimated from $\mathrm{SO}_{4}{ }^{2-}$, $\mathrm{Na}^{+}$, and $\mathrm{Ca}^{+}$ions based on a previous method [27]. Additionally, biomass burning-derived $\mathrm{K}^{+}$was estimated from $\mathrm{K}^{+}$, sea salt $\mathrm{K}^{+}$, and crustal $\mathrm{K}^{+}$ions [27]. Sea salt $\mathrm{K}^{+}$and crustal $\mathrm{K}^{+}$ions were derived from $\mathrm{Na}^{+}$and non-sea salt $\mathrm{Ca}^{2+}$, respectively.

The Teflon filter sample was also used for element determination by an energy dispersive X-ray fluorescence spectrometer (ED-XRF) at Cooper Environmental Services (Portland, OR, USA). In total, forty-eight elements ( $\mathrm{Na}, \mathrm{Mg}, \mathrm{Al}, \mathrm{Si}, \mathrm{P}, \mathrm{S}, \mathrm{Cl}, \mathrm{K}, \mathrm{Ca}, \mathrm{Sc}, \mathrm{Ti}, \mathrm{V}, \mathrm{Cr}, \mathrm{Mn}, \mathrm{Fe}, \mathrm{Co}, \mathrm{Ni}, \mathrm{Cu}, \mathrm{Zn}, \mathrm{Ga}, \mathrm{As}, \mathrm{Se}$, $\mathrm{Br}, \mathrm{Rb}, \mathrm{Sr}, \mathrm{Y}, \mathrm{Zr}, \mathrm{Nb}, \mathrm{Mo}, \mathrm{Ag}$, Cd, In, Sn, Sb, Cs, Ba, La, Ce, Sm, Eu, Tb, Hf, Ta, W, Ir, Au, Hg, and Pb) were analyzed by ED-XRF. The limit of detections (LODs) were in the range of $0.99-51.24 \mathrm{ng} / \mathrm{cm}^{2}$. The average relative percent difference of duplicate samples was $4.12 \%$.

The quartz filter samples were used to analyze carbonaceous species. OC and EC were determined using a $1.0-\mathrm{cm}^{2}$ punched filter and analyzed using the Sunset Laboratory OC-EC Aerosol Analyzer (5 L, Sunset laboratory, Portland, OR, USA). The LODs for OC and EC were $0.2 \mu \mathrm{g} / \mathrm{m}^{3}$ obtained from the lowest sucrose spike injection experiments. Replicate analyses and external calibration checks were conducted at the rate of one per every 10 samples and 15 samples, respectively. The thermal-optical transmittance (TOT) method [28] was employed using the National Institute for Occupational Safety and Health (NIOSH) 5040 temperature protocol. Water-soluble organic carbon (WSOC) was determined using a total organic carbon (TOC) analyzer (Sievers 900, General Electric, Boulder, CO, USA). The quartz filter samples were extracted in 30-mL DI water and ultrasonicated for $2 \mathrm{~h}$ at constant water temperature $\left(20^{\circ} \mathrm{C}\right)$. The water extract was passed through a polyvinylidene fluoride (PVDF) syringe filter. An inorganic carbon remover (ICR) was employed to minimize the effects of inorganic carbon on TOC measurements [29]. The LOD for the TOC, calculated as 3 times the standard deviation of field blank filter value, was $0.067 \mu \mathrm{gC} / \mathrm{m}^{3}$. Replicate analyses were conducted at the rate of one per every 10 samples. The determined repeatability was better than $5 \%$.

For the determination of organic molecular markers, the quartz filter sample was extracted by sonication using dichloromethane for nonpolar organic compounds (NPOrC) and water or methanol for polar organic compounds (POrC). NPOrC (i.e., n-alkanes (33 compounds), cycloalkanes (5), steranes and hopanes (16), and PAHs (22)) were analyzed using gas chromatography-electron impact-mass spectrometry (GC-EI-MS) and POrC (i.e., alkanoic acids (25), resin acids (8), aromatic diacids (8), alkanedioic acids (8), levoglucosan, and sterols (6)) were quantified using tandem liquid mass spectrometry (LC-MSMS). All data was blank corrected using field blank data. For each NPOrC sample, the final volume was adjusted to $500 \mu \mathrm{L}$ to match the volume of the internal standard (samples and blanks were spiked with internal standards). 
Analysis of POrC is challenging due to the analytically sialylation difficulties using GC-MS. For this reason, underivatized POrC were analyzed using LC-MSMS. With internal standards (e.g., phthalic acid (D4)), the DI water of $5.0 \mathrm{~mL}$ (or methanol for some POrC (e.g., sterols, phthalates, etc.) was spiked into the sample tube for the final extract volume. Hydrophilic interaction LC used an Eclipse XDB-C18 $4.6 \mathrm{~mm}$ ID $\times 150 \mathrm{~mm}(5 \mathrm{~mm}$ ) column (Agilent, Palo Alto, CA, USA) as the stationary phase with $10 \mathrm{mM}$ ammonium acetate and acetonitrile in DI water. POrC was analyzed in multiple reaction monitoring (MRM) mode for the separation and detection of underivatized compounds. Regression coefficients of determination for seven-point calibrations were from 0.998 to 0.999 . Absolute MDLs were in the range of $1.7-4.6 \mathrm{pg} / \mathrm{m}^{3}$. For all POrC, the final mass fragment transitions of quantification purpose (i.e., fragmentor voltage, collision energy, quantifier, and qualifier ions) were determined.

The quartz filter samples were extracted using dichloromethane (DCM) to determine the total organic characteristics. The DCM extract was filtered using a PTFE syringe filter and then dried under a nitrogen stream. The dried extract was redissolved in 50\% (v/v) DCM and toluene and then analyzed by a 15 Tesla (15T) Fourier transform ion cyclotron resonance mass spectrometer (FT-ICR-MS). The FT-ICR-MS was equipped with an atmospheric pressure photoionization (APPI) source in positive ion mode. The FT-ICR-MS operating conditions were as follows: syringe pump flow rate of $500 \mu \mathrm{L} / \mathrm{h}$ (SolariX XRTM System, Bruker Daltonics, Billerica, MA, USA), capillary voltage of $1000 \mathrm{~V}$ for APPI, drying gas flow rate of $4.0 \mathrm{~L} / \mathrm{min}$ for APPI, drying gas temperature of $220^{\circ} \mathrm{C}$ for APPI, an ion accumulation time of $0.05 \mathrm{~s}$, and a transient length of $1.39 \mathrm{~s}$. The FT-ICR-MS data were processed using a commercial software (DataAnalysis, ver. 4.2, Bruker Daltonics, Billerica, MA, USA and Composer, Sierra Analytics, Modesto, CA, USA) to assign organic groups (CHO, CHN, CHS, CHON, and CHONS organic groups). Constraint on the maximum number of atoms were set to 200 for ${ }^{12} \mathrm{C}, 400$ for ${ }^{1} \mathrm{H}$, 50 for ${ }^{16} \mathrm{O}, 4$ for ${ }^{14} \mathrm{~N}$, and 2 for ${ }^{32} \mathrm{~S}$ atoms for the calculations of the molecular formula. After this, the molecular formulas with assignment errors higher than $0.3 \mathrm{ppm}$, and those from the blank filter extract were excluded from further processing. The amount of each organic group (number percent) was calculated by dividing the number of mass peaks of each organic group by the total assigned organic mass peaks. The double bond equivalent (DBE) value representing the sum of the rings and double bonds in each molecule (the degree of unsaturation in the given compound) was calculated from the number of atoms in the chemical formula $\left(\mathrm{DBE}=1+\mathrm{n}_{\mathrm{C}}-0.5 \mathrm{n}_{\mathrm{H}}+0.5 \mathrm{n}_{\mathrm{N}}\right)$ [30]. The potential presence of aromatic structures in a molecule was examined by calculating the aromaticity index (AI) [31].

A two-dimensional gas chromatography/high-resolution mass spectrometer (GC $\times \mathrm{GC} / \mathrm{HRMS}$ ) (Pegasus GC-HRT 4D, LECO, St. Joseph, MI, USA) was connected to an Agilent 7890A gas chromatographer (Agilent, Palo Alto, CA, USA) with a thermal modulator between the primary and secondary columns. The GC $\times$ GC/HRMS peaks were processed with a signal-to-noise ratio greater than 100 and within the accuracy of $5 \mathrm{ppm}$. The peak area percent of PAHs (\%) was calculated by dividing the peak area of PAHs by the total WISOC peak area in GC $\times$ GC/HRMS chromatograms.

The quartz filter samples were cut to $3 \mathrm{~cm} \times 4 \mathrm{~cm}$ using ceramic scissors for determination of $\mathrm{Pb}$ istope ratios. The cuttings were completely digested in a 4:1:1 mixture of $\mathrm{HNO}_{3}, \mathrm{HClO}_{4}$, and $\mathrm{HF}$, followed by a 4:1 mixture of $\mathrm{HNO}_{3}$ and HF. Cation and trace element concentrations were measured using an inductively coupled plasma-atomic emission spectrometer (ICP-AES) (Optima 8300, Perkin Elmer, Waltham, MA, USA) and an inductively coupled plasma-mass spectrometer (ICP-MS) (iCAP ${ }^{\mathrm{TM}}$ Q, Thermo Elemental, Waltham, MA, USA). Repeated analyses of standard particle samples (SRM 2783, NIST, Baltimore, MD, USA) on the filter media yielded an external reproducibility of $< \pm 5 \%$. Detailed descriptions of $\mathrm{Pb}$ purification and isotope measurements are given in a previous study [32]. In brief, the samples were dried in Teflon beakers, and the residues were treated with concentrated $\mathrm{HNO}_{3}$. The samples were then dried and redissolved in $2 \mathrm{~N} \mathrm{HCl}$. A Pb-resin (100-150 $\left.\mu \mathrm{m}\right)$ (Eichrom Technologies, Darien, IL, USA) was used to separate $\mathrm{Pb}$ from matrix elements. After loading the sample, matrix elements were eluted with $4 \mathrm{~mL}$ of $2 \mathrm{~N} \mathrm{HCl}$, and $\mathrm{Pb}$ was collected in $6 \mathrm{~mL}$ of $6 \mathrm{~N}$ $\mathrm{HCl}$. The $\mathrm{Pb}$ isotope ratios were measured using a multicollector-inductively coupled plasma-mass spectrometer (MC-ICP-MS) (Neptune, Thermo Scientific, Waltham, MA, USA) upgraded with a large 
dry interface pump. The sample was introduced into a quartz dual cyclonic spray chamber, and sample intensities were matched within $10 \%$ of the intensity of the standard. To correct instrumental mass fractionation and mass bias effects during the measurements, a thallium isotopic standard (NIST SRM 997) $\left({ }^{205} \mathrm{Tl} /{ }^{203} \mathrm{Tl}=2.38714\right)$ was added to the $\mathrm{Pb}$ fraction, inducing a 5:1 ratio of $\mathrm{Pb}$ and $\mathrm{Tl}$. A statistical analysis was conducted to compare $\mathrm{Pb}$ isotope ratios between two sites by using student's $t$-test (SPSS) (version 21, IBM SPSS Statistics, Armonk, NY, USA).

Gas $\left(\mathrm{O}_{3}, \mathrm{NO}_{2}, \mathrm{CO}\right.$, and $\left.\mathrm{SO}_{2}\right)$ data were obtained from gas analyzers (models $49 \mathrm{i}, 42 \mathrm{i}, 48 \mathrm{i}$, and 43i; Thermo Fisher Scientific, Waltham, MA, USA) at the Beijing site and the Korean Meteorological Administration (KMA) site, which is $\sim 2 \mathrm{~km}$ away from the Gwangju site. An automatic weather station (AWS) was used to measure meteorological data (relative humidity (RH), temperature, wind direction, and wind speed) at the Beijing and Gwangju sites. The Hybrid Single-Particle Lagrangian Integrated Trajectory (HYSPLIT) model (version 4) of the National Oceanic and Atmospheric Administration (NOAA) Air Resources Laboratory (ARL) and meteorological data from the Global Data Assimilation System (GDAS) of the National Centers for Environmental Information (NCEI) database were used to calculate air mass backward trajectories [33]. The 72-h air mass backward trajectories were calculated every hour using the HYSPLIT model with an endpoint height of $100 \mathrm{~m}$ at the receptor site. In total, 720 air mass backward trajectories were obtained during the sampling period. Clustering of the air mass backward trajectory data was attempted to classify major air masses affecting the receptor sites.

\section{Results and Discussion}

The spatial variability of average $\mathrm{PM}_{2.5}$ mass concentrations throughout the sampling period is shown in Figure 2. The $\mathrm{PM}_{2.5}$ mass concentrations represent average values obtained from all available sites for each specific province (161 sites in China (https://www.aqistudy.cn/) and 286 sites in Korea (https://www.airkorea.or.kr)). Highest $\mathrm{PM}_{2.5}$ mass concentrations can be observed in inland regions (Henan) in China. The North China Plain (NCP) is one of the most polluted regions in China [34]. The Hebei Province is heavily industrial, harboring steel, ceramic, petroleum, and pharmaceutical industries, and has the highest coal consumption in China [35,36]. Henan, Shanxi, and Shandong are also known to be heavily polluted, industrialized, and urbanized regions [35,37]. The $\mathrm{PM}_{2.5}$ produced from these heavily polluted provinces can be transported to other nearby provinces [35]. The central regions (Chungbuk) in Korea had the highest $\mathrm{PM}_{2.5}$ mass concentrations during the sampling period. The west of Chungbuk is surrounded by mountains favoring the accumulation of $\mathrm{PM}_{2.5}$. In addition, several coal power plants located west of Chungbuk may also influence elevated $\mathrm{PM}_{2.5}$ in Chungbuk.

The Beijing site had higher wind speeds $(2.6 \mathrm{~m} / \mathrm{s})$ and lower RH $(26.6 \%)$ and temperature $\left(-3.9^{\circ} \mathrm{C}\right)$ compared to the Gwangju site $\left(0.5 \mathrm{~m} / \mathrm{s}, 66.5 \%\right.$, and $-0.8{ }^{\circ} \mathrm{C}$, respectively). Daily $\mathrm{PM}_{2.5}$ mass concentrations (filter-based data), including gaseous data, are shown in Figure 3. Based on the daily $\mathrm{PM}_{2.5}$ mass concentrations, three and two $\mathrm{PM}_{2.5}$ events were identified at the Beijing and Gwangju sites, respectively. The average $\mathrm{PM}_{2.5}$ mass concentrations during the whole sampling period was 62.5 $\mu \mathrm{g} / \mathrm{m}^{3}$ in Beijing and $26.8 \mu \mathrm{g} / \mathrm{m}^{3}$ in Gwangju. Daily mass concentrations of major chemical components (ions, OC, EC, and elements) in $\mathrm{PM}_{2.5}$ are also included in Figure 3. The "unknown" indicates the difference between $\mathrm{PM}_{2.5}$ mass concentration determined by gravimetrical method and the sum of mass concentrations of all measured chemical components in $\mathrm{PM}_{2.5}$. The proportion of elements (35.9\%) and OC $(24.6 \%)$ in $\mathrm{PM}_{2.5}$ in Beijing were much higher than in Gwangju (11.7\% and $16.9 \%$, respectively). The proportion of ions in $\mathrm{PM}_{2.5}$ was higher in Gwangju (49.6\%) than in Beijing (21.7\%). The EC proportion in $\mathrm{PM}_{2.5}$ was similar between Beijing (3.2\%) and Gwangju (3.5\%). The dry conditions and high wind speeds, and its proximity to the desert at the Beijing site, favor dust generation, including road and construction dust, and influence the high element concentrations in $\mathrm{PM}_{2.5}$ and $\mathrm{PM}_{2.5}$ mass concentrations. This was also supported by the increased dust elements at the Beijing site, as will be discussed later. Average concentrations of gases $\left(\mathrm{NO}_{2}, \mathrm{SO}_{2}, \mathrm{O}_{3}\right.$, and $\left.\mathrm{CO}\right)$ are summarized in Table $\mathrm{S} 2$ in supplementary material. Higher $\mathrm{NO}_{2}$ (contributing to secondary aerosols) and $\mathrm{CO}$ (primary combustion emission) concentrations were observed at the Beijing site than Gwangju. 


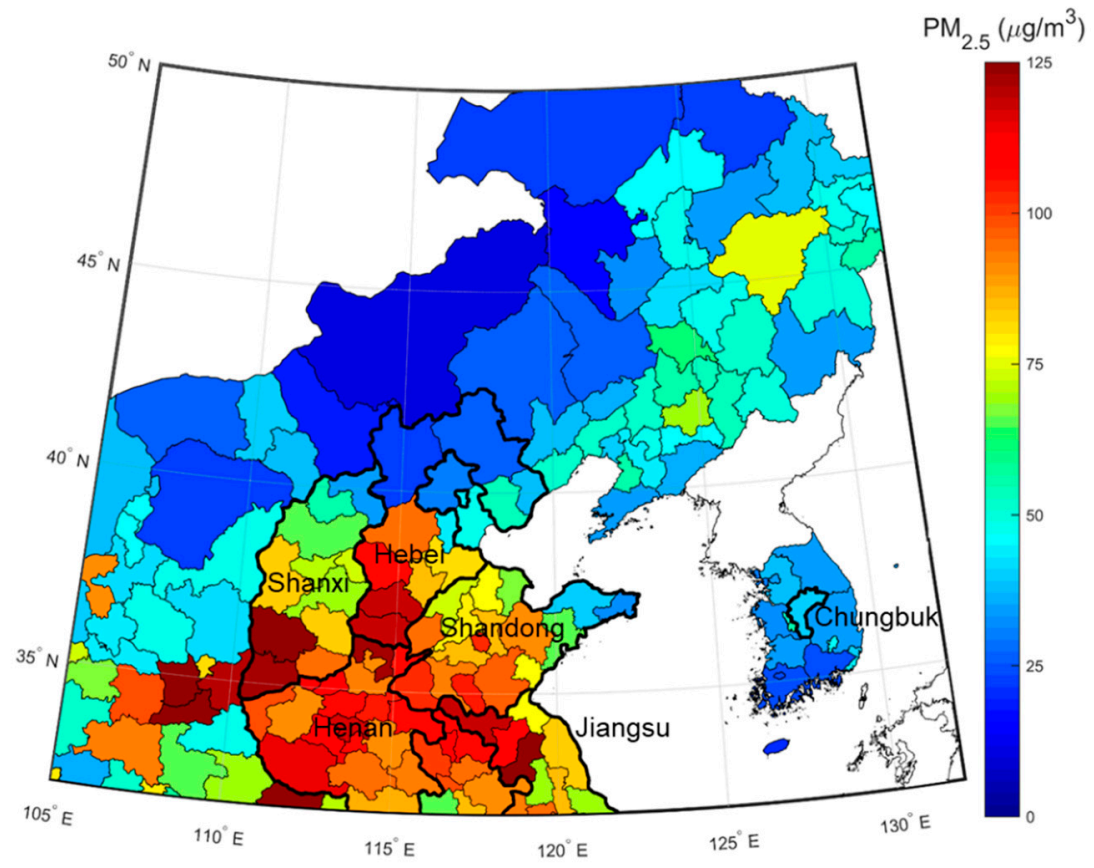

Figure 2. Spatial distribution of average $\mathrm{PM}_{2.5}$ mass concentrations in China and Korea during the sampling period from 3 January 2018 to 2 February 2018.
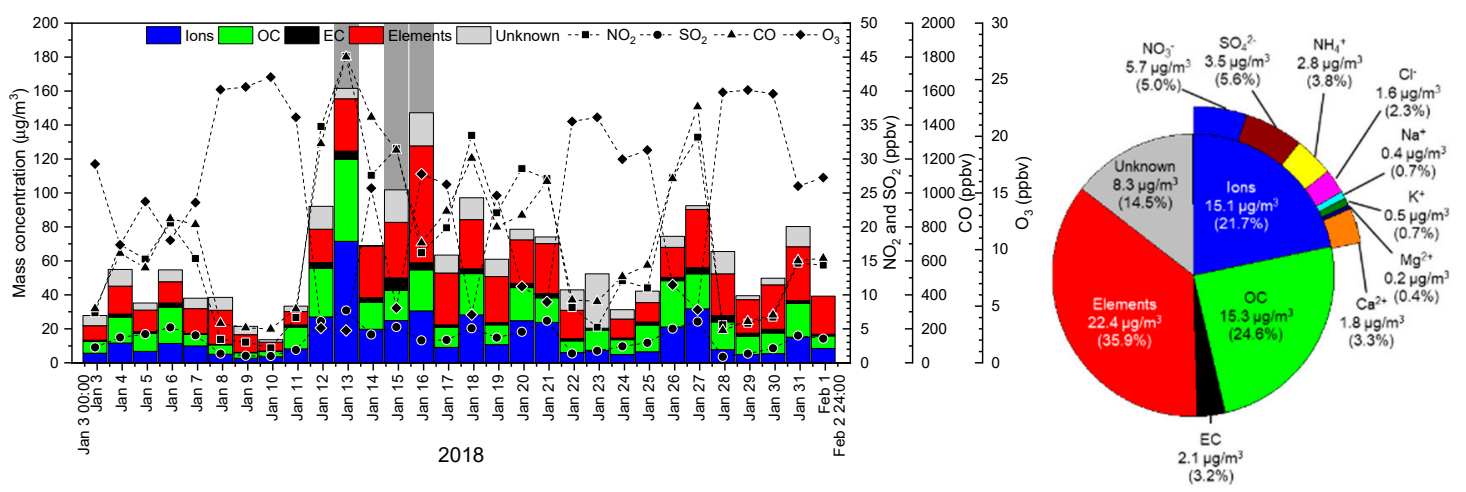

(a)
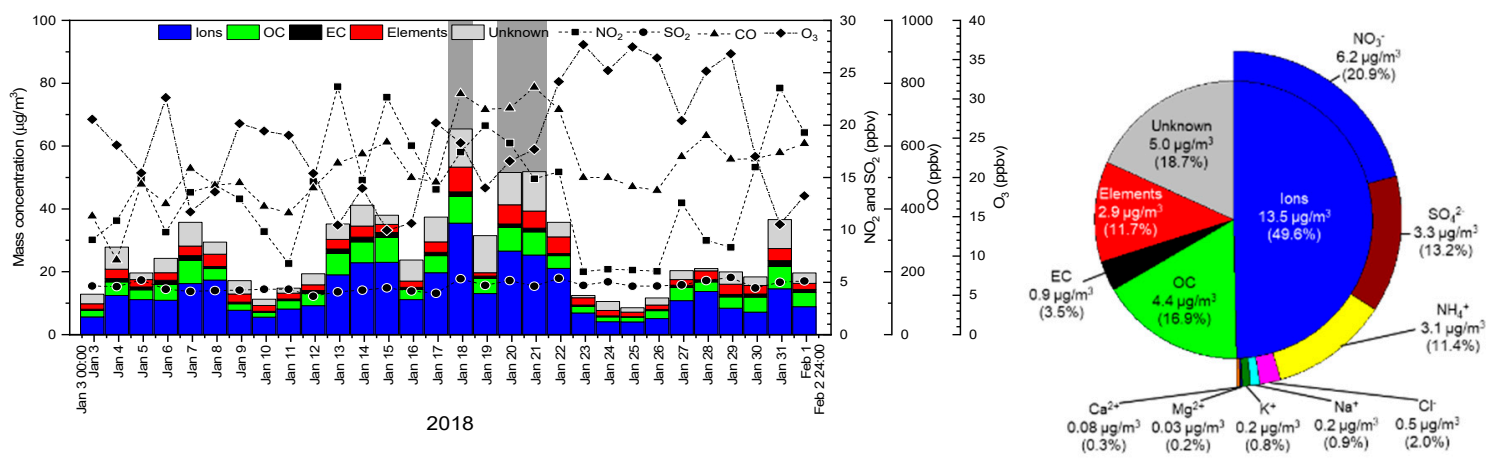

(b)

Figure 3. Daily mass concentrations and average values of $\mathrm{PM}_{2.5}$, gases, and major chemical components in $\mathrm{PM}_{2.5}$ at the (a) Beijing and (b) Gwangju sites (the dark-gray shading indicates $\mathrm{PM}_{2.5}$ events in Beijing and Gwangju). 
We compared the chemical characteristics of $\mathrm{PM}_{2.5}$ in the two urban sites, as shown in Figure 4. In particular, the mass fractions of the chemical components in $\mathrm{PM}_{2.5}$ were compared and are summarized in Table S3 in supplementary material. We observed higher fractions of $\mathrm{Ca}^{2+}, \mathrm{Mg}^{2+}$, and $\mathrm{Cl}^{-}$in Beijing relative to Gwangju and higher $\mathrm{NO}_{3}{ }^{-}$and $\mathrm{NH}_{4}{ }^{+}$fractions in Gwangju relative to Beijing. $\mathrm{Ca}, \mathrm{Fe}, \mathrm{Mg}, \mathrm{Si}, \mathrm{Al}, \mathrm{Mn}, \mathrm{K}$, and $\mathrm{Pb}$ fractions in $\mathrm{PM}_{2.5}$ were significantly higher in Beijing, while $\mathrm{Sb}, \mathrm{Cs}$, $\mathrm{Br}, \mathrm{Cd}, \mathrm{S}$, As, and $\mathrm{Zn}$ fractions in $\mathrm{PM}_{2.5}$ were higher in Gwangju. Based on known ionic and elemental markers [38], these observations suggest that Beijing suffered higher contributions from coal burning $\left(\mathrm{Cl}^{-}\right)$and dust $(\mathrm{Ca}, \mathrm{Fe}, \mathrm{Si}$, and $\mathrm{Al})$ sources relative to Gwangju.

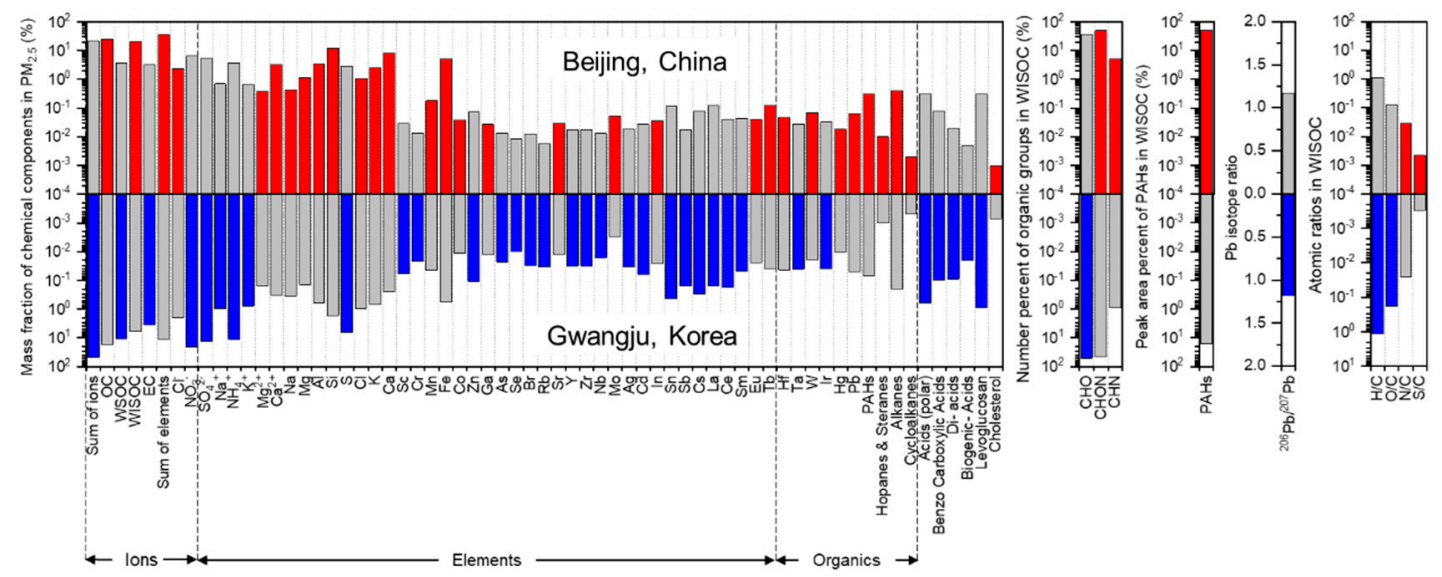

Figure 4. Comparison of the mass fractions of chemical components and other measured parameters of $\mathrm{PM}_{2.5}$ in Beijing (China) and Gwangju (Korea): the red color indicates measured parameters with higher fractions in Beijing relative to Gwangju, and the blue color indicates parameters with higher fractions in Gwangju relative to Beijing.

The WSOC fraction in $\mathrm{PM}_{2.5}$ was higher in Gwangju (10.9\%) than in Beijing (4.0\%), and the WSOC/OC ratio, which can be used as a secondary organic aerosol (SOA) indicator [39], was also higher in Gwangju (66\%) than in Beijing (16\%), suggesting that secondary and/or aged carbonaceous species dominated the OC fraction of $\mathrm{PM}_{2.5}$ in Gwangju [39,40]. The WSOC variability was positively correlated with $\mathrm{NO}_{3}{ }^{-}\left(\mathrm{r}=0.96\right.$ in Beijing and $\mathrm{r}=0.93$ in Gwangju); $\mathrm{NH}_{4}{ }^{+}(\mathrm{r}=0.97$ in Beijing and $\mathrm{r}=0.91$ in Gwangju); non-sea salt $\mathrm{SO}_{4}{ }^{2-}(\mathrm{r}=0.92$ in Beijing and $\mathrm{r}=0.64$ in Gwangju); and organic acids (e.g., sum of acids (polar), benzo carboxyl acids, di- acids, and biogenic acids) ( $r=0.93$ in Beijing and $r=0.91$ in Gwangju) in both sites, which suggests that secondary formation of ions and the WSOC occurred simultaneously. The WSOC variability also correlated well with levoglucosan $(r=0.86$ in Beijing and $r=0.86$ in Gwangju) and biomass burning-derived $\mathrm{K}^{+}(\mathrm{r}=0.85$ in Beijing and $\mathrm{r}=0.78$ in Gwangju), suggesting the importance of biomass burning source contributions to the WSOC. It was reported that biomass burning significantly contributed to the WSOC fraction in $\mathrm{PM}_{2.5}$ [39,41].

The fractions of PAHs, hopanes and steranes, alkanes, cycloalkanes, and cholesterol in $\mathrm{PM}_{2.5}$ or $\mathrm{OC}$ were much higher (2.6 to 10.4 times for $\mathrm{PM}_{2.5}$ fraction and 1.8 to 7.2 times for $\mathrm{OC}$ fraction) in Beijing than in Gwangju, implying higher contributions of primary (fresh) organic compounds from various combustion sources to the total $\mathrm{PM}_{2.5}$ organic content in Beijing relative to Gwangju. Although the fraction of EC was similar in Beijing and Gwangju, the EC concentration in Beijing was higher than Gwangju. In contrast, the relative contributions of organic acids (e.g., sum of acids (polar), benzo carboxyl acids, di- acids, and biogenic acids) and sugar/levoglucosan to the $\mathrm{PM}_{2.5}$ and the total $\mathrm{PM}_{2.5}$ organic content were higher (2.5 to 2.9 times for $\mathrm{PM}_{2.5}$ fraction and 3.4 to 3.8 times for OC fraction) in Gwangju than in Beijing. Our data therefore implies a higher contribution of secondary organic aerosols and biomass burning sources to the total $\mathrm{PM}_{2.5}$ organic content in Gwangju relative to Beijing. Although the contributions were lower in Beijing relative to Gwangju, the absolute mass concentrations 
of organic acids and sugar/levoglucosan were higher, suggesting that secondary organic aerosols and biomass burning sources had still significantly contributed to the $\mathrm{PM}_{2.5}$ organic content in Beijing.

The WISOC fraction in $\mathrm{PM}_{2.5}$ was much higher in Beijing (20.7\%) than in Gwangju (5.8\%). The N/C and $\mathrm{S} / \mathrm{C}$ ratios of WISOC increased in Beijing, while the $\mathrm{H} / \mathrm{C}$ and $\mathrm{O} / \mathrm{C}$ ratios increased in Gwangju. The $\mathrm{CHO}$ organic groups (in terms of number percents in mass peaks) in WISOC were more dominant in Gwangju relative to Beijing, while the $\mathrm{CHON}$ and $\mathrm{CHN}$ organic groups were more dominant in Beijing. The $\mathrm{CHON}$ and $\mathrm{CHN}$ organic groups may be derived from the combination of organic and nitrate or organic-nitrogen compounds [42]. The CHON groups (e.g., nitro-aromatics) are primarily emitted from biomass burning and are also formed via the reactions between anthropogenic VOCs and $\mathrm{NO}_{x}$ [43]. The $\mathrm{CHN}$ organic groups are also mainly produced from biomass burning [44,45]. Contribution of levoglucosan (biomass burning marker) to $\mathrm{PM}_{2.5}$ was higher in Gwangju, while CHON and CHN groups were more dominant in WISOC in Beijing, suggesting that other combustion sources in addition to biomass burning contributed to the $\mathrm{CHON}$ and $\mathrm{CHN}$ organic groups. Organo-sulfates can also form via the reaction between oxidized VOC products and acidic sulfate [46]. More detailed discussion on organic groups in WISOC and WSOC (i.e., CHO, CHN, CHS, CHON, and CHONS organic groups) will be presented in our paper in preparation [47].

Based on high mass resolution data (GC $\times$ GC/HRMS), the peak area percent (\%) of PAHs in WISOC was higher in Beijing (51.9\%) relative to Gwangju (16.3\%), suggesting that various primary combustion sources contributed to the PAHs in Beijing. Further, we observed more oxygenated PAHs and azaarenes in Gwangju compared with Beijing.

Various natural and anthropogenic sources, such as coal, vehicles, paint, waste incineration, smelting, and metallurgy, can affect the $\mathrm{Pb}$ concentrations and isotope ratios in $\mathrm{PM}_{2.5} . \mathrm{Pb}$ isotope ratios $\left({ }^{206} \mathrm{~Pb} /{ }^{207} \mathrm{~Pb}\right.$ and $\left.{ }^{208} \mathrm{~Pb} /{ }^{207} \mathrm{~Pb}\right)$ are known to vary depending on their sources (coal, petrol, industrial, paint, and ore) [48-50]. The ${ }^{206} \mathrm{~Pb} /{ }^{207} \mathrm{~Pb}$ ratio was somewhat lower in Beijing (1.166) than Gwangju (1.176), while the ${ }^{208} \mathrm{~Pb} /{ }^{207} \mathrm{~Pb}$ ratio was similar in range for both cities (Beijing $=2.444$ and Gwangju $=2.439)$. Both $\mathrm{Pb}$ isotope ratios were close to values typically associated with industry and coal sources $[48,51-54]$, suggesting that the $\mathrm{Pb}$ at both sites were anthropogenically sourced. The lower ${ }^{206} \mathrm{~Pb} /{ }^{207} \mathrm{~Pb}$ ratio indicates that industry and coal sources should be more responsible for the $\mathrm{Pb}$ in Beijing, relative to Gwangju $(p<0.05)$.

We investigated the characteristics of the winter $\mathrm{PM}_{2.5}$ events at the Beijing site. Three $\mathrm{PM}_{2.5}$ events were observed in Beijing, and each event showed different chemical characteristics. The chemical species which experienced the largest increase in mass fractions between nonevent and event days differed for each $\mathrm{PM}_{2.5}$ event, as shown in Figure 5. We compared the average mass fraction values of each chemical component between $\mathrm{PM}_{2.5}$ event days and nonevent days.

In $\mathrm{PM}_{2.5}$ event $1, \mathrm{~K}^{+}, \mathrm{Cl}^{-}, \mathrm{NO}_{3}{ }^{-}$, and organic acids in $\mathrm{PM}_{2.5}$ increased significantly with a low wind speed, suggesting that primary combustion aerosols from biomass burning and coal burning, and the secondary formation of nitrate and organics, contributed to the elevated $\mathrm{PM}_{2.5}$ concentrations under stagnant conditions. Under stagnant conditions, concentrations of $\mathrm{NO}_{2}, \mathrm{SO}_{2}$, and $\mathrm{CO}$ also increased (Table S2 and Figure S1 in supplementary material). The acid fractions (polar and benzo carboxylic acids) increased significantly, suggesting that secondary organic aerosols (SOA) contributed to the increase in $\mathrm{PM}_{2.5}$. The percentage of $\mathrm{CHON}$ and $\mathrm{CHN}$ in WISOC increased from $41.0 \%$ to $49.1 \%$ and $3.6 \%$ to $6.4 \%$, respectively, in $\mathrm{PM}_{2.5}$ event 1 compared to nonevent days, indicating the formation of organic-nitrogen compounds which can originate from biomass burning and/or form by secondary process.

In $\mathrm{PM}_{2.5}$ event 2, EC showed the highest increase, followed by $\mathrm{K}^{+}$and $\mathrm{Cl}^{-}$with low wind speeds, suggesting the highest $\mathrm{PM}_{2.5}$ contributions from primary combustion aerosols emitted from vehicles (diesel) increased significantly with biomass burning under stagnant conditions. The percentage of CHON and $\mathrm{CHN}$ organic groups in WISOC increased from $41.0 \%$ to $43.5 \%$ and $3.6 \%$ to $4.2 \%$, respectively, in $\mathrm{PM}_{2.5}$ event 2 compared to nonevent days, indicating the formation of organic-nitrogen compounds. 


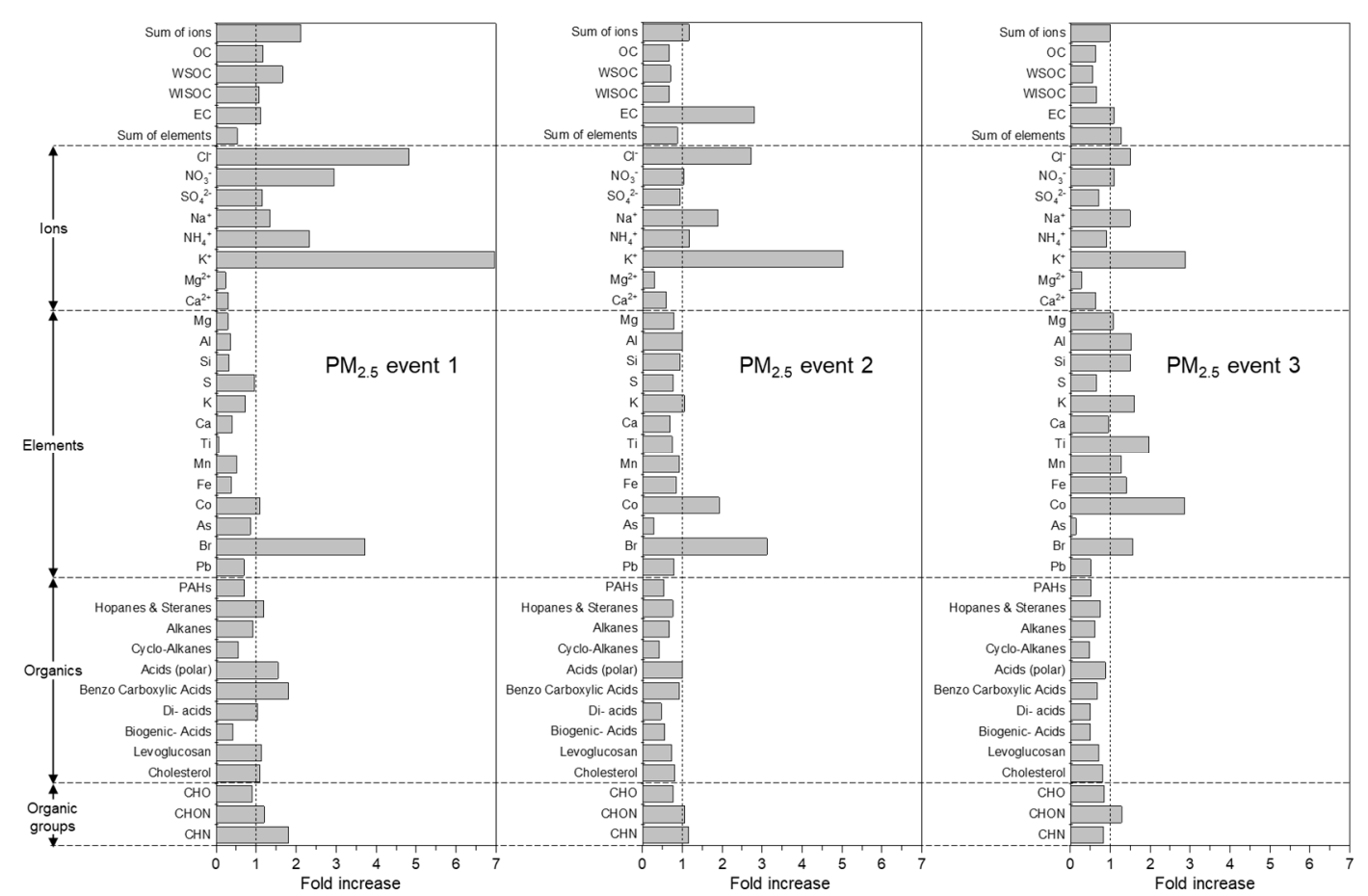

Figure 5. The mass fraction fold increases of chemical components in $\mathrm{PM}_{2.5}$ and other measured parameters during the winter $\mathrm{PM}_{2.5}$ events compared to nonevent days at the Beijing (China) site.

High mass resolution data also indicated the peak area percent of PAHs, hopanes, and sugar in WISOC in $\mathrm{PM}_{2.5}$ events 1 and 2 increased compared to nonevent days, suggesting that the diversity of primary combustion sources increased in the $\mathrm{PM}_{2.5}$ events. DBE (unsaturation index) and $\mathrm{AI}$ also increased in $\mathrm{PM}_{2.5}$ events 1 and 2, inferring a higher number of aromatic compounds and unsaturated organics in WISOC (16.75 of DBE and 0.51 of $\mathrm{AI}$ in $\mathrm{PM}_{2.5}$ event 1 , and 14.37 of DBE and 0.40 of $\mathrm{AI}$ in $\mathrm{PM}_{2.5}$ event 2) relative to nonevent days (13.49 of DBE and 0.37 of $\mathrm{AI}$ ).

Four clusters of air masses (west and northwest (slow-moving), northwest (fast-moving), north (fast-moving), and north (slow-moving)) occurred in the region during the whole sampling period, as shown in Figure 6a. The slow-moving west and northwest air mass (black line in Figure 6a) dominated during both $\mathrm{PM}_{2.5}$ event 1 and 2, also supporting that stagnant conditions played an important role in elevated $\mathrm{PM}_{2.5}$ during the winter $\mathrm{PM}_{2.5}$ events. The RH increased in both $\mathrm{PM}_{2.5}$ event $1(35 \% \pm 8 \%$ $\mathrm{RH})$ and $2(41 \% \pm 5 \% \mathrm{RH})$ compared to the average value $(21 \% \pm 4 \% \mathrm{RH})$ in nonevent days. Although organic groups in WSOC were not measured in this study, it was reported that organo-sulfates formed in humid conditions via aqueous phase pathways, contributing to WSOC in $\mathrm{PM}_{2.5}$ [45]. It is not certain that the elevated RH during the events were sufficient for the WSOC to form significantly.

Elevated dust levels-identified by the significant increase in mineral elements in $\mathrm{PM}_{2.5}$-was the primary cause for the high levels of $\mathrm{PM}_{2.5}$ during $\mathrm{PM}_{2.5}$ event 3 . The fast-moving northwest air mass (red line in Figure 6a) that passed through the inner Mongolia area dominated during the $\mathrm{PM}_{2.5}$ event 3 dust event. The fast-moving air mass can bring or resuspend relatively larger particles such as desert, road, and construction dust as a result of higher wind speeds compared to nonevent days. The $\mathrm{PM}_{2.5-10}$ mass concentrations (coarse mode particles) also increased in $\mathrm{PM}_{2.5}$ event 3 , as shown in Figure S2 in supplementary material. 


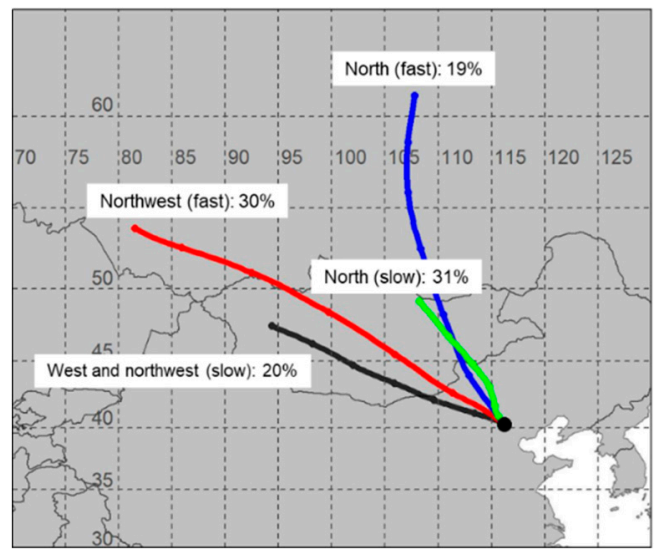

(a)

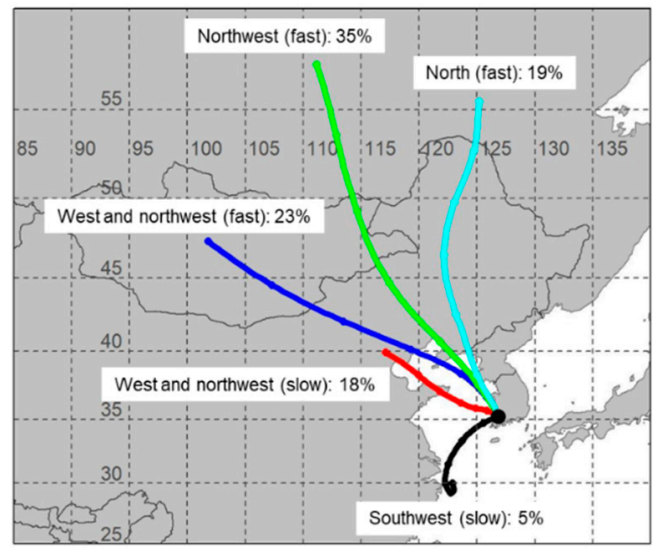

(b)

Figure 6. Major clusters of air mass backward trajectories in (a) Beijing (China) and (b) Gwangju (Korea) during the sampling period (72-h air mass backward trajectories arriving at the receptor site at the height of $100 \mathrm{~m})$.

The $\mathrm{Pb}$ isotope ratio $\left({ }^{206} \mathrm{~Pb} /{ }^{207} \mathrm{~Pb}\right)$ showed little difference between the $\mathrm{PM}_{2.5}$ events and nonevent days in Beijing, suggesting that the $\mathrm{Pb}$ origin (industry and coal) in $\mathrm{PM}_{2.5}$ events little differed relative to nonevent days. Our data suggests that the contents of $\mathrm{PM}_{2.5}$ during winter $\mathrm{PM}_{2.5}$ events in Beijing are predominantly influenced by multiple primary combustion sources (biomass burning, vehicle emission, and coal burning) and secondary formation sources under stagnant conditions and/or dust sources under high wind speeds.

Figure 7 shows the characteristics of $\mathrm{PM}_{2.5}$ during the two identified winter $\mathrm{PM}_{2.5}$ events at the Gwangju site. We observed similar chemical characteristics during both $\mathrm{PM}_{2.5}$ events. Both $\mathrm{PM}_{2.5}$ events were characterized by lower RH and wind speeds compared to average values on nonevent days. As with $\mathrm{PM}_{2.5}$ events 1 and 2 in Beijing, stagnant conditions (low wind speeds) also played an important role in the Gwangju $\mathrm{PM}_{2.5}$ events. Five clusters of air masses (southwest (slow-moving), west and northwest (slow-moving), west and northwest (fast-moving), northwest (fast-moving), and north (fast-moving)) were identified, as shown in Figure 6b. The slow-moving west and northwest air mass (red line in Figure 6b) was most dominant during the Gwangju PM $\mathrm{PM}_{2.5}$ events, which also played an important role in elevated $\mathrm{PM}_{2.5}$ during the winter $\mathrm{PM}_{2.5}$ events in the Gwangju site. $\mathrm{NO}_{3}{ }^{-}, \mathrm{Pb}$, and $\mathrm{K}$ showed the highest mass fraction increase in $\mathrm{PM}_{2.5}$ during the Gwangju $\mathrm{PM}_{2.5}$ events. Additionally, sugar/levoglucosan and organic-acids fractions increased significantly, suggesting significant particle contribution from biomass burning and secondary nitrate and organic aerosols. Additionally, the percentage of CHON organic groups increased in WISOC from $42.5 \%$ to $55.0 \%$ and $42.5 \%$ to $61.5 \%$ in 
$\mathrm{PM}_{2.5}$ events 1 and 2, respectively, compared to nonevent days. As with the Beijing events, our results suggest the formation of organic-nitrogen compounds which can originate from biomass burning and form by the secondary process during the Gwangju $\mathrm{PM}_{2.5}$ events.

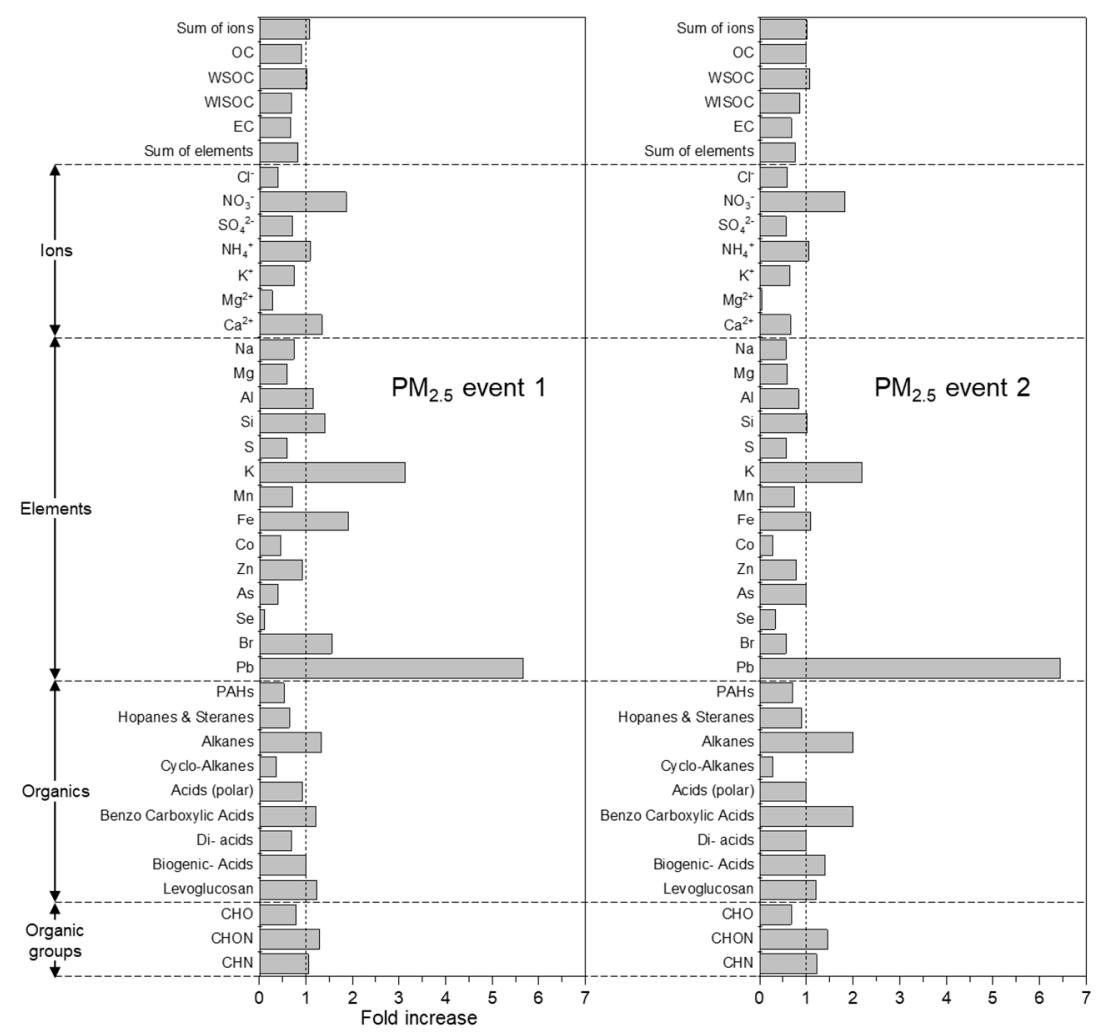

Figure 7. The mass fraction fold increases of chemical components in $\mathrm{PM}_{2.5}$ and other measured parameters during winter $\mathrm{PM}_{2.5}$ events compared to nonevent days at the Gwangju (Korea) site.

Based on high mass resolution organic data, the fraction of sugar in WISOC increased by a factor of three during the $\mathrm{PM}_{2.5}$ events compared to nonevent days. The peak area percent of PAHs in WISOC decreased from $19.7 \%$ to $12.0 \%$ and $19.7 \%$ to $10.8 \%$ in $\mathrm{PM}_{2.5}$ events 1 and 2, respectively, which is in contrast to the observed increases in percent PAHs during all of the Beijing $\mathrm{PM}_{2.5}$ events, suggesting that the diversity of PAHs-emitting primary combustion sources did not significantly increase in the Gwangju $\mathrm{PM}_{2.5}$ events. The $\mathrm{Pb}$ isotope ratios $\left({ }^{206} \mathrm{~Pb} /{ }^{207} \mathrm{~Pb}\right)$ significantly decreased in the Gwangju $\mathrm{PM}_{2.5}$ events, compared to the nonevent days (from 1.194 to 1.164) $(p<0.05)$, indicative of the increase of industry source contribution to the $\mathrm{Pb}$ relative to nonevent days, which was in contrast to Beijing, where little variability between $\mathrm{PM}_{2.5}$ events and nonevent days was observed.

The stagnant conditions played an important role in $\mathrm{PM}_{2.5}$ events in both countries, except the dust event, which only occurred with high wind speeds in Beijing. We observed the increases of biomass burning sources and secondary formations of nitrate and organic aerosols in the winter $\mathrm{PM}_{2.5}$ events in both countries, but we observed more diversity in sources contributing to the $\mathrm{PM}_{2.5}$ events in Beijing relative to Gwangju.

\section{Conclusions}

We identified three $\mathrm{PM}_{2.5}$ events in Beijing. Compared to nonevent days, $\mathrm{K}^{+}, \mathrm{Cl}^{-}, \mathrm{NO}_{3}{ }^{-}$, and organic acids showed the highest increases in $\mathrm{PM}_{2.5}$ event $1, \mathrm{EC}, \mathrm{K}^{+}$, and $\mathrm{Cl}^{-}$showed the highest increases in $\mathrm{PM}_{2.5}$ event 2, and mineral elements showed the highest increases in $\mathrm{PM}_{2.5}$ event 3 . The west and northwest slow-moving air masses dominated in $\mathrm{PM}_{2.5}$ events 1 and 2, inferring stagnant conditions. In contrast, the northwest fast-flowing air mass dominated in $\mathrm{PM}_{2.5}$ event 3 , 
transporting desert wind-blown dust to the city. Our data suggest that a combination of multiple primary combustion sources (biomass burning, coal burning, and vehicle emissions) and secondary aerosol formation under stagnant conditions and/or dust sources under high wind speeds contributed to the winter $\mathrm{PM}_{2.5}$ events at the Beijing site. Two $\mathrm{PM}_{2.5}$ events were identified in Gwangju, which were characterized by the highest increases in $\mathrm{NO}_{3}{ }^{-}, \mathrm{K}, \mathrm{Pb}$, and organic acids. The west and northwest slow-moving air masses dominated during the $\mathrm{PM}_{2.5}$ events in Gwangju.

The stagnant conditions played an important role in $\mathrm{PM}_{2.5}$ events in both countries, except the dust event, which only occurred with high wind speeds in Beijing. We observed the increases of organic-nitrogen compounds ( $\mathrm{CHON}$ and $\mathrm{CHN}$ groups) and biomass burning markers in the winter $\mathrm{PM}_{2.5}$ events in both countries, but we observed more diversity in sources contributing to the $\mathrm{PM}_{2.5}$ events in Beijing relative to Gwangju. Pb isotope ratios indicated that industry and coal sources' contributions to the $\mathrm{Pb}$ increased in Gwangju $\mathrm{PM}_{2.5}$ events relative to nonevent days, which was in contrast to Beijing, where little variability between $\mathrm{PM}_{2.5}$ events and nonevent days was observed. The clear differences observed in the chemical characteristics of the winter $\mathrm{PM}_{2.5}$ events between the two urban sites suggest that different control strategies for $\mathrm{PM}_{2.5}$ are necessary for effective atmospheric remediation.

Supplementary Materials: The following are available online at http://www.mdpi.com/2073-4433/11/3/292/s1: Figure S1: Daily variations of wind speeds during all sampling periods and $\mathrm{PM}_{2.5}$ events at (a) Beijing and (b) Gwangju. Figure S2: Hourly variations of $\mathrm{PM}_{2.5-10}$ mass concentrations in the Beijing $\mathrm{PM}_{2.5}$ events 1, 2, and 3 . Table S1: A summary of measured parameters at the Beijing and Gwangju sites. Table S2: Average concentrations of gases $\left(\mathrm{NO}_{2}, \mathrm{SO}_{2}, \mathrm{O}_{3}\right.$, and $\left.\mathrm{CO}\right)$ and meteorological data (temperature, relative humidity, and wind speed) at the Beijing and Gwangju sites during all sampling periods, nonevent days, and $\mathrm{PM}_{2.5}$ events. Table S3: Average concentrations and mass fractions (\%) of chemical components (ions, OC, EC, and elements) in $\mathrm{PM}_{2.5}$ at the Beijing and Gwangju sites from 3 Jan 2018 to 1 Feb 2018.

Author Contributions: Conceptualization, K.P.; formal analysis, K.P., M.P. (Minhan Park), H.L., M.-S.B., K.-S.J, Y.H.K., and J.-S.R.; investigation, M.P. (Minhan Park), Y.W., J.C., H.L., J.J., H.S., N.K., L.J.S.B., H.M., E.M.R.C., M.C.F.J.D., S.C., I.S., M.C., M.P. (Moonhee Park), and S.P.; supervision, K.P. and M.H.; visualization, M.P. (Minhan Park), J.J., and H.L.; writing—original draft, K.P. and M.P. (Minhan Park); and writing—review and editing, K.P., M.P. (Minhan Park), Y.W., M.-S.B., K.-S.J., Y.H.K., and M.H. All authors discussed and approved the content of the manuscript.

Funding: This research was supported by the National Leading Research Laboratory Program (NRF-2019R1A2C3007202) and the PM 2.5 Research Project (NRF-2017M3D8A1092220) funded by the Ministry of Science and ICT (MSIT) and the National Research Foundation (NRF) of Korea.

Conflicts of Interest: The authors declare that there are no conflicts of interest.

\section{References}

1. Pöschl, U. Atmospheric aerosols: Composition, transformation, climate and health effects. Angew. Chem. 2005, 44, 7520-7540. [CrossRef] [PubMed]

2. Pope, C.A., III; Dockery, D.W. Health effects of fine particulate air pollution: Lines that connect. J. Air Waste Manag. Assoc. 2006, 56, 709-742. [CrossRef] [PubMed]

3. Shindell, D.; Faluvegi, G.; Walsh, M.; Anenberg, S.C.; Dingenen, R.V.; Muller, N.Z.; Austin, J.; Koch, D.; Milly, G. Climate, health, agricultural and economic impacts of tighter vehicle-emission standards. Nat. Clim. Chang. 2011, 1, 59-66. [CrossRef]

4. D'Amato, G.; Pawankar, R.; Vitale, C.; Lanza, M.; Molino, A.; Stanziola, A.; Sanduzzi, A.; Vatrella, A.; D'Amato, M. Climate change and air pollution: Effects on respiratory allergy. AAIR 2016, 8, 391-395. [CrossRef]

5. Heo, J.; Adams, P.J.; Gao, H.O. Public health costs of primary $\mathrm{pm}_{2.5}$ and inorganic $\mathrm{pm}_{2.5}$ precursor emissions in the United States. Environ. Sci. Technol. 2016, 50, 6061-6070. [CrossRef]

6. Lee, W.; Shen, L.; Catalano, P.J.; Mickley, L.J.; Koutrakis, P. Effects of future temperature change on $\mathrm{PM}_{2.5}$ infiltration in the Greater Boston area. Atmos. Environ. 2017, 150, 98-105. [CrossRef]

7. Hien, P.D.; Bac, V.T.; Tham, H.C.; Nhan, D.D.; Vinh, L.D. Influence of meteorological conditions on $\mathrm{PM}_{2.5}$ andPM $\mathrm{P}_{2.5-10}$ concentrations during the monsoon season in Hanoi, Vietnam. Atmos. Environ. 2002, 36, 3473-3484. [CrossRef] 
8. DeGaetano, A.T.; Doherty, O.M. Temporal, spatial and meteorological variations in hourly $\mathrm{PM}_{2.5}$ concentration extremes in New York City. Atmos. Environ. 2004, 38, 1547-1558. [CrossRef]

9. Xu, J.W.; Martin, R.V.; van Donkelaar, A.; Kim, J.; Choi, M.; Zhang, Q.; Geng, G.; Liu, Y.; Ma, Z.; Huang, L.; et al. Estimating ground-level $\mathrm{PM}_{2.5}$ in eastern China using aerosol optical depth determined from the GOCI satellite instrument. Atmos. Chem. Phys. 2005, 15, 13133-13144. [CrossRef]

10. Song, C.K.; Ho, C.H.; Park, R.J.; Choi, Y.S.; Kim, J.; Gong, D.Y.; Lee, Y.B. Spatial and seasonal variations of surface $\mathrm{PM}_{10}$ concentration and modis aerosol optical depth over China. Asia-Pac. J. Atmos. Sci. 2009, 45, 33-43.

11. Tian, G.; Liu, X.; Kong, L. Spaiotemporal patterns and cause analysis of $\mathrm{PM}_{2.5}$ concentrations in Beijing, China. Hindawi 2018, 15, 1-8. [CrossRef]

12. Wang, J.; Zhang, M.; Bai, X.; Tan, H.; Li, S.; Liu, J.; Zhang, R.; Wolters, M.A.; Qin, X.; Zhang, M.; et al. Large-scale transport of PM2.5 in the lower troposphere during winter cold surges in China. Sci. Rep. 2017, 7, 13238. [CrossRef] [PubMed]

13. Sun, Y.; Zhuang, G.; Tang, A.; Wang, Y.; An, A. Chemical characteristics of $\mathrm{PM}_{2.5}$ and $\mathrm{PM}_{10}$ in haze-fog episodes in Beijing. Environ. Sci. Technol. 2006, 40, 3148-3155. [CrossRef] [PubMed]

14. Shang, X.; Zhang, K.; Meng, F.; Wang, S.; Lee, M.; Suh, I.; Kim, D.; Jeon, K.; Park, H.; Wang, X.; et al. Characteristics and source apportionment of fine haze aerosol in Beijing during the winter of 2013. Atmos. Chem. Phys. 2018, 18, 2573-2584. [CrossRef]

15. Gao, J.; Tian, H.; Chen, K.; Lu, L.; Zhen, M.; Wang, S.; Hao, J.; Wang, K.; Hua, S.; Zhu, C.; et al. The variation of chemical characteristics of $\mathrm{PM}_{2.5}$ and $\mathrm{PM}_{10}$ and formation causes during two haze pollution events in urban Beijing, China. Atmos. Environ. 2015, 107, 1-8. [CrossRef]

16. Kim, H.S.; Huh, J.B.; Hopke, P.K.; Holsen, T.M.; Yi, S.M. Characteristics of the major chemical constituents of $\mathrm{PM}_{2.5}$ and smog events in Seoul, Korea in 2003 and 2004. Atmos. Environ. 2007, 41, 6762-6770. [CrossRef]

17. Choi, J.K.; Heo, J.B.; Ban, S.J.; Yi, S.M.; Zoh, K.D. Chemical characteristics of $\mathrm{PM}_{2.5}$ aerosol in Incheon, Korea. Atmos. Environ. 2012, 60, 583-592. [CrossRef]

18. Yu, G.H.; Park, S.S.; Park, J.S.; Park, S.M.; Song, I.H.; Oh, J.; Shin, H.J.; Lee, M.D.; Lim, H.B.; Kim, H.W.; et al. Pollution characteristics of $\mathrm{PM}_{2.5}$ observed during Winter and Summer in Baengryeongdo and Seoul. J. Korean Soc. Atmos. Environ. 2018, 34, 38-55. [CrossRef]

19. Park, S.S.; Kim, Y.J.; Fung, K. Characteristics of $\mathrm{PM}_{2.5}$ carbonaceous aerosol in the Sihwa industrial area, South Korea. Atmos. Environ. 2001, 35, 657-665. [CrossRef]

20. Borlaza, L.J.S.; Cosep, E.M.R.; Kim, S.; Lee, K.; Joo, H.; Park, M.; Bate, D.; Cayetano, M.G.; Park, K. Oxidative potential of fine ambient particles in various environments. Environ. Pollut. 2018, 243, 1679-1688. [CrossRef]

21. Lee, K.Y.; Batmunkh, T.; Joo, H.S.; Park, K. Comparison of the physical and chemical characteristics of fine road dust at different urban sites. J. Air Waste Manag. Assoc. 2018, 68, 812-823. [CrossRef] [PubMed]

22. Kourtchev, I.; O'Connor, I.P.; Giorio, C.; Fuller, S.J.; Kristensen, K.; Maenhaut, W.; Wenger, J.C.; Sodeau, J.R.; Glasius, M.; Kalberer, M. Effects of anthropogenic emissions on the molecular composition of urban organic aerosols: An ultrahigh resolution mass spectrometry study. Atmos. Environ. 2014, 89, 525-532. [CrossRef]

23. Xue, J.; Li, Y.; Xie, X.; Xiong, C.; Liu, H.; Chen, S.; Nie, Z.; Chen, C.; Zhao, J. Characterization of organic aerosol in Beijing by laser desorption ionization coupled with Fourier Transform Ion Cyclotron Resonance Mass spectrometry. Atmos. Environ. 2017, 159, 55-65. [CrossRef]

24. Dewan, N.; Majestic, B.J.; Ketterer, M.E.; Miller-Schulze, J.P.; Shafer, M.M.; Schauer, J.J.; Solomon, P.A.; Artamonova, M.; Chen, B.B.; Imashev, S.A.; et al. Tracing Dust Sources Using Stable Lead and Strontium Isotopes in Central Asia. In Trace Materials in Air, Soil, and Water; Evans, K.R., Roberts-Kirchhoff, E.S., Benvenuto, M.A., Lanigan, K.C., Rihana-Abdallah, A., Eds.; American Chemical Society: Washington, DC, USA, 2015; pp. 79-98.

25. Wang, S.; Hu, G.; Yan, Y.; Wang, S.; Yu, R.; Cui, J. Source apportionment of metal elements in PM 2.5 in a coastal city in Southeast China: Combined Pb-Sr-Nd isotopes with PMF method. Atmos. Environ. 2019, 198, 302-312. [CrossRef]

26. Zhang, Y.; Li, X.; Nie, T.; Qi, J.; Chen, J.; Wu, Q. Source apportionment of $\mathrm{PM}_{2.5}$ pollution in the central six districts of Beijing, China. J. Clean. Prod. 2018, 174, 661-669. [CrossRef]

27. Pio, C.A.; Legrand, M.; Alves, C.A.; Oliveira, T.; Afonso, J.; Caseiro, A.; Puxbaum, H.; Sanchez-Ochoa, A.; Gelencśer, A. Chemical composition of atmospheric aerosols during the 2003 summer intense forest fire period. Atmos. Envrion. 2008, 42, 7530-7543. [CrossRef] 
28. Birch, M.E.; Cary, R.A. Elemental carbon-based method for monitoring occupational exposures to particulate diesel exhaust. Aerosol Sci. Technol. 1996, 25, 221-241. [CrossRef]

29. Bae, M.S.; Lee, T.; Schauer, J.J.; Park, G.; Son, Y.B.; Kim, K.H.; Cho, S.S.; Park, S.S.; Park, K.; Shon., Z.H. Chemical characteristics of size-resolved aerosols in coastal areas during KORUS-AQ campaign; comparison of ion neutralization model. Asia-Pac. J. Atmos. Sci. 2018, 1-13. [CrossRef]

30. Hockaday, W.C.; Grannas, A.M.; Kim, S.; Hatcher, P.G. Direct molecular evidence for the degradation and mobilityof black carbon in soils from ultrahigh-resolution massspectral analysis of dissolved organic matter from afire-impacted forest soil. Org. Geochem. 2006, 37, 501-510. [CrossRef]

31. Koch, B.P.; Dittmar, T. From mass to structure: An aromaticity index for high-resolutionmass data of natural organic matter. Rapid Commun. Mass Spectrom. 2016, 30, 250. [CrossRef]

32. Choi, H.B.; Ryu, J.S.; Park, S.; Lee, J. Lead isotope measurement using a multi-collector inductively coupled plasma mass spectrometry (MC-ICP-MS). J. Geol. Soc. Korea. 2018, 54, 311-318. [CrossRef]

33. Draxler, R.R.; Hess, G.D. An overview of the HYSPLIT_4 modeling system for trajectories, dispersion, and deposition. Aust. Meteor. Mag. 1998, 47, 295-308.

34. Du, J.; Zhang, X.; Huang, T.; Gao, H.; Mo, J.; Mao, X.; Ma, J. Removal of $\mathrm{PM}_{2.5}$ and secondary inorganic aerosols in the North China Plain by dry deposition. Sci. Total Environ. 2019, 651, 2312-2322. [CrossRef] [PubMed]

35. Wang, L.T.; Wei, Z.; Yang, J.; Zhang, Y.; Zhang, F.F.; Su, J.; Meng, C.C.; Zhang, Q. The 2013 severe haze over southern Hebei, China: Model evaluation, source apportionment, and policy implications. Atmos. Chem. Phys. 2014, 14, 3151-3173. [CrossRef]

36. Huang, X.; Liu, Z.; Liu, J.; Hu, B.; Wen, T.; Tang, G.; Zhang, J.; Wu, F.; Ji, D.; Wang, L.; et al. Chemical characterization and source identification of $\mathrm{PM}_{2.5}$ at multiple sites in the Beijing-Tianjin-Hebei region, China. Atmos. Chem. Phys. 2017, 17, 12941-12962. [CrossRef]

37. Lu, X.; Lin, C.; Li, W.; Chen, Y.; Huang, Y.; Fung, J.C.H.; Lau, A.K.H. Analysis of the adverse health effects of $\mathrm{PM}_{2.5}$ from 2001 to 2017 in China and the role of urbanization in aggravating the health burden. Sci. Total Environ. 2019, 652, 683-695. [CrossRef]

38. Xue, H.; Liu, G.; Zhang, H.; Hu, R.; Wang, X. Similarities and differences in $\mathrm{PM}_{10}$ and $\mathrm{PM}_{2.5}$ concentrations, chemical compositions and sources in Hefei City, China. Chemosphere 2019, 220, 760-765. [CrossRef]

39. Xiang, P.; Zhou, X.; Duan, J.; Tan, J.; He, K.; Yuan, C.; Ma, Y.; Zhang, Y. Chemical characteristics of water-soluble organic compounds (WSOC) in $\mathrm{PM}_{2.5}$ in Beijing, China: 2011-2012. Atmos. Res. 2017, 183, 104-112. [CrossRef]

40. Wen, J.; Shi, G.; Tian, Y.; Chen, G.; Liu, J.; Huang-Fu, Y.; Ivey, C.E.; Feng, Y. Source contributions to water-soluble organic carbon and water-insoluble organic carbon in $\mathrm{PM}_{2.5}$ during Spring Festival, heating and non-heating seasons. Ecotoxicol. Environ. Saf. 2018, 164, 172-180. [CrossRef]

41. Ram, K.; Sarin, M.M.; Tripathi, S.N. Temporal trends in atmospheric PM2.5, PM10, elemental carbon, organic carbon, water-soluble organic carbon, and optical properties: Impact of biomass burning emissions in the indo-gangetic plain. Environ. Sci. Technol. 2011, 46, 686-695. [CrossRef]

42. Schurman, M.I.; Lee, T.; Desyaterik, Y.; Schichtel, B.A.; Kreidenweis, S.M.; Collett Jr., J.L. Transport, biomass burning, and in-situ formation contribute tofineparticle concentrations at a remote site near Grand Teton National Park. Atmos. Environ. 2015, 112, 257-268. [CrossRef]

43. Wang, Y.; Hu, M.; Wang, Y.; Zheng, J.; Shang, D.; Yang, Y.; Liu, Y.; Li, X.; Tang, R.; Zhu, W.; et al. The formation of nitro-aromatic compounds under high $\mathrm{NO}_{\mathrm{x}}$ and anthropogenic VOC conditions in urban Beijing, China. Atmos. Chem. Phys. 2019, 19, 7649-7665. [CrossRef]

44. Lin, P.; Rincon, A.G.; Kalberer, M.; Yu, J.Z. Elemental composition of HULIS in the Pearl River Delta Region, China: Results inferred from positive and negative electrospray high resolution mass spectrometric data. Environ. Sci. Technol. 2012, 46, 7454-7462. [CrossRef] [PubMed]

45. Wang, Y.; Hu, M.; Lin, P.; Guo, Q.; Wu, Z.; Li, M.; Zeng, L.; Song, Y.; Zeng, L.; Wu, Y.; et al. Molecular characterization of nitrogen-containing organic compounds in humic-like substances emitted from straw residue burning. Environ. Sci. Technol. 2017, 51, 5951-5961. [CrossRef] [PubMed]

46. Wang, Y.; Hu, M.; Guo, S.; Wang, Y.; Zheng, J.; Yang, Y.; Zhu, W.; Tang, R.; Li, X.; Liu, Y.; et al. The secondary formation of organosulfates under interactions between biogenic emissions and anthropogenic pollutants in summer in Beijing. Atmos. Chem. Phys. 2018, 18, 10693-10713. [CrossRef] 
47. Jang, K.-S.; Choi, M.; Park, M.; Park, M.H.; Kim, Y.H.; Seo, J.; Wang, Y.; Hu, M.; Bae, M.-S.; Park, K. Assessment of PM2.5-derived nitrogen-containing organic compounds during winter at urban sites in China and Korea. manuscript in preparation. Unpublished work. 2020.

48. Komárek, M.; Ettler, V.; Chrastný, V.; Mihaljevič, M. Lead isotopes in environmental sciences: A review. Envrion. Int. 2008, 34, 562-577. [CrossRef] [PubMed]

49. Zhu, L.; Tang, J.; Lee, B.; Zhang, Y.; Zhang, F. Lead concentrations and isotopes in aerosols from Xiamen, China. Mar. Pollut. Bull. 2010, 60, 1946-1955. [CrossRef]

50. Zhao, Y.; Yua, R.; Hua, G.; Lin, X.; Liu, X. Chemical characteristics and Pb isotopic compositions of $\mathrm{PM}_{2.5}$ in Nanchang, China. Particuology 2017, 32, 95-102. [CrossRef]

51. Mukai, H.; Furuta, N.; Fujii, T.; Ambe, Y.; Sakamoto, K.; Hashimoto, Y. Characterizatlon of sources of lead in the urban air of Asia using ratios of stable lead isotopes. Environ. Sci. Technol. 1993, 27, 1347-1356. [CrossRef]

52. Mukai, H.; Tanaka, A.; Fujii, T. Regional characteristics of sulfur and lead isotope ratios in the atmosphere at several Chinese urban sites. Envrion. Sci. Technol. 2001, 35, 1064-1071. [CrossRef]

53. Zhu, B.Q.; Chen, Y.W.; Peng, J.H. Lead isotope geochemistry of the urban environment in the Pearl River Delta. Appl. Geochem. 2001, 16, 409-417. [CrossRef]

54. Widory, D.; Liu, X.; Dong, S. Isotopes as tracers of sources of lead and strontium in aerosols $\left(\mathrm{TSP}_{\mathrm{S}}\right.$ \& $\left.\mathrm{PM}_{2.5}\right)$ in Beijing. Atmos. Environ. 2010, 44, 3679-3687. [CrossRef]

(C) 2020 by the authors. Licensee MDPI, Basel, Switzerland. This article is an open access article distributed under the terms and conditions of the Creative Commons Attribution (CC BY) license (http://creativecommons.org/licenses/by/4.0/). 